УДК 553.94:550.4

\title{
ЭЛЕМЕНТЫ-ПРИМЕСИ В УГЛЯХ МЕСТОРОЖДЕНИЯ ФАНДЮШКИНСКОЕ ПОЛЕ (БЕРИНГОВСКИЙ КАМЕННОУГОЛЬНЫЙ БАССЕЙН, ЧУКОТКА)
}

\author{
Скиба Дарья Александровна', \\ dariaskib@bk.ru
}

\author{
Кузеванова Евгения Владимировна², \\ e.kuzevanova@oilmsu.ru \\ Шишов Евгений Павлович1, \\ e-shishov@mail.ru \\ 1 Всероссийский научно-исследовательский геологический институт им. А.П. Карпинского, \\ Россия, 199106, г. Санкт-Петербург, Средний пр., 74. \\ 2 Московский государственный университет им. М.В. Ломоносова, \\ Россия, 119991, г. Москва, ГСП-1, Ленинские Горы, 1.
}

\begin{abstract}
Актуальность. Изучение возможности комплексной переработки углей Беринговского каменноугольного бассейна на предмет извлечения различных элементов-примесей вызвано необходимостью повышения уровня экономического развития и безопасности Чукотского автономного округа. Это особенно важно в контексте его географического расположения в районе Крайнего Севера и труднодоступности. В настоящее время из-за довольно высокой себестоимости добычи и повышенной зольности (до 30 \%) угли нижних пачек месторождения «Фандюшкинское поле» пользуются небольшим спросом на рынке, хотя составляют значительную часть запасов. Потенциальная возможность оценки данных уәлей еще и с точки зрения наличия попутных полезных компонентов могла бы увеличить ценность добываемого сырья.

Цель: определить перспективность территории на предмет повышенных содержаний элементов-примесей и выявить направления дальнейших исследований.

Объекты: Беринговский каменноугольный бассейн, угленосные отложения позднемелового возраста Алькатваамского угленосного района, месторождение «Фандюшкинское поле» и его фрланги.

Методы: отбор проб, построение литологических колонок и разрезов, инструментальный нейтронно-активационный анализ. Результаты. Дана геохимическая характеристика углей месторождения «Фандюшкинское поле» (Алькатваамский угленосный район, Чукотский автономный округ) на основе данных, полученных с помощью инструментального нейтронноактивационного анализа. Установлено, что в углях месторождения «Фандюшкинсоке поле» Беринговского каменноугольного бассейна и его фрлангов концентрации цинка, стронция, гафрния, скандия и редкоземельных элементов находятся на уровне минимально-промышленных содержаний в известных типах руд. Данные о содержании некоторых элементов-примесей в углях изученного месторождения публикуются впервые.
\end{abstract}

\section{Ключевые слова:}

Каменные угли, элементы-примеси в углях, редкие металлы, редкоземельные элементы, инструментальный нейтронно-активационный анализ, Чукотка.

\section{Введение}

Ископаемые угли относятся к важным концентраторам редких и ценных металлов [1-4]. Современные аналитические методы расширяют возможность изучения механизмов их накопления в угольных месторождениях. Обнаружение рудных концентраций ценных элементов-примесей в углях Чукотки могло бы послужить важным стимулом для экономического развития региона, так как сможет существенно повысить стоимость извлекаемого полезного ископаемого. Это особенно важно для отдаленных северных территорий России со слабо развитой инфраструктурой [5, 6]. В статье приводятся результаты проведенного авторами исследования особенностей распределения элементов-примесей и их концентрации в углях месторождения «Фандюшкинское поле» Беринговского каменноугольного бассейна.

\section{Угленосность}

Угленосность Беринговского бассейна связана с чукотской свитой палеоцен-эоценового возраста, ко- рякской и барыковской свитами позднемелового возраста. В работах $[7,8]$ описаны три угленосных района: район Бухты Угольной, Алькатваамский, Амаамский, и несколько углепроявлений. Угли месторождения «Фандюшкинское поле» приурочены к верхней подсвите корякской свиты Алькатваамского угленосного района. Особый интерес представляет угольный пласт «Одинокий». Пласт состоит из двух угольных пачек: Верхняя и Нижняя, которые расщепляются на Верхнюю-1, Верхнюю-2 и Нижнюю-1, Нижнюю-2. Пласт имеет сложное строение с довольно изменчивым количеством и мощностью породных прослоев. Общая мощность пласта местами может достигать 25-28 м [9].

\section{Ранее проведенные исследования}

Спектральным анализом в углях месторождения «Бухта Угольная» оценены содержания $\mathrm{Pb}, \mathrm{Cr}, \mathrm{Ni}, \mathrm{Sn}$, $\mathrm{Ag}, \mathrm{Zn}, \mathrm{Co}$. Высокие содержания (\%) характерны для Sr $(0,05-0,3), \mathrm{V}(0,004-0,06)$, Ва $(0,01-0,03)$ и $\mathrm{Ti}$ $(0,1-0,5)[10]$. 
Во время геологоразведочных работ в 2007-2010 и в 2013 гг. были проведены аналитические исследования на содержание в углях попутных полезных компонентов в Амаамском и Алькатваамском угленосных районах Беринговского каменноугольного бассейна. Для Амаамского угленосного района были отобраны пробы I, II, III и IV пластов, для Алькатваамского - пачки Верхняя-1 и Верхняя-2 угольного пласта «Одинокий». Исследования проводились в «Becquerel laboratories» (Канада) и в лаборатории SGS Vostok Limited (г. Новокузнецк). Были использованы следующие методы: нейтронноактивационный, ICP-MS и пробирный. Определялось содержание в сухом угле 28 элементов: $\mathrm{Sb}, \mathrm{Cs}$, $\mathrm{Cr}, \mathrm{Co}, \mathrm{F}, \mathrm{Au}, \mathrm{Mn}, \mathrm{V}$; As, Be, Bi, B, Cd, Cu, Ga, Ge, Pb, Hg, Mo, Ni, Re, Se, Ag, Te, Sn, W, Zn; Pt. Высоких концентраций редких и рассеянных элементов не установлено $[7,8]$.

\section{Фактический материал и результаты исследования}

В 2019 г. для изучения элементов-примесей был выполнен инструментальный нейтронно-активационный анализ (ИНАА) на 28 элементов ( $\mathrm{Sm}, \mathrm{Ce}, \mathrm{Ca}, \mathrm{Lu}, \mathrm{U}, \mathrm{Th}$, $\mathrm{Cr}, \mathrm{Yb}, \mathrm{Au}, \mathrm{Hf}, \mathrm{Ba}, \mathrm{Sr}, \mathrm{Nd}, \mathrm{As}, \mathrm{Ag}, \mathrm{Br}, \mathrm{Cs}, \mathrm{Tb}, \mathrm{Sc}, \mathrm{Rb}, \mathrm{Fe}$, $\mathrm{Zn}, \mathrm{Ta}, \mathrm{Co}, \mathrm{Na}, \mathrm{Eu}, \mathrm{La}, \mathrm{Sb})$. Анализ выполнен на базе НИ ТПУ (г. Томск) в лаборатории ядерно-геохимических методов исследования (зав. лаб. А.Ф Судыко). Для анализа было подготовлено 140 штуфных проб. Пробы были отобраны из основных угольных пачек угольного пласта «Одинокий» (рис. 1). Аналитические исследования на содержание элементов-примесей для пачек Нижняя-1 и Нижняя-2 были выполнены впервые.

По результатам анализа была проведена статистическая обработка данных [11-13]. В табл. 1, 2 приведены средние значения, максимальные и минимальные содержания для каждого элемента по каждой отдельной пачке пласта в пересчете на золу.

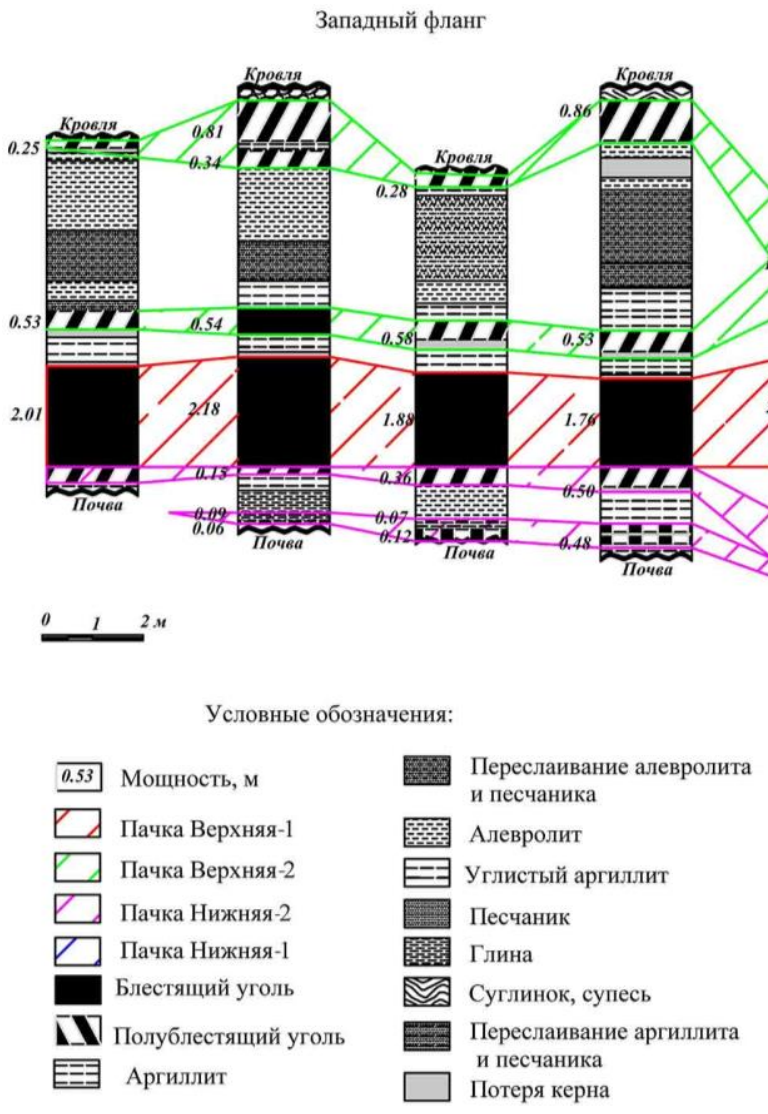

Рис. 1. Литологические колонки опробованных скважин

Fig. 1. Lithology columns of sampled holes

Для оценки уровня концентрации того или иного химического элемента в углях были сопоставлены их содержания с кларками элементов-примесей в золе каменных углей. Это позволило выявить геохимическую специализацию изучаемого угольного бассейна (района), а также обратить внимание на элементы, содержания которых могут достигать промышленных концентраций (рис. 2, 3).

Строниий. В пачках Верхняя-1 и Верхняя-2 средние содержания элемента в золе составляют 424 и
1118 г/т соответственно. Максимальные содержания по отдельным пробам до $1,46 \%$. В нижних пачках содержания стронция не превышают 58,5 г/т.

Цинк. По всем четырем пачкам пласта среднее содержание цинка от 232 до 709,5 г/т в золе, что составляет от 1,3 (в верхних пачках) до 4 (в нижних пачках) кларков. Максимальное содержание в $1,32 \%$ отмечается в пачке Верхняя-1.

Кобальт. Повышенные средние содержания кобальта приурочены к пачкам Верхняя-1 и Верхняя-2. 
Они превышают кларковые значения от полутора до пяти раз и достигают 199 г/т в золе. Максимальное содержание составляет 600 г/т. Для нижних пачек средние содержания не достигают кларковых значений.

Хром. Содержание хрома во всех пачках угольного пласта приближается к околокларковым значениям.

Иттриевая подгруппа редкоземельных элементов - иттербий, тербий, лютеций. Суммарное среднее содержание элементов данной подгруппы находится на уровне околокларковых, и только в пачке Нижняя-1 отмечаются высокие концентрации, превышающие кларк в 3 раза (37 г/т в золе). Максимальное содержание в пачке Нижняя-1 составляет 105 г/т. Также стоит отметить повышенное содержание отдельного элемента - иттербия - в пачке Верхняя-2. Оно составляет 13 г/т в золе, что почти в 2 раза выше кларка.

Цериевая подгруппа редкоземельных элементов самарий, иерий, неодим, европий, лантан. Суммарное среднее содержание элементов данной подгруппы распределено по пачкам пласта неравномерно. Наибольшая концентрация приурочена к пачке Нижняя-1, где в среднем составляет 476 г/т в золе (1,5 раза выше кларка). Максимальная концентрация в этой же пачке достигает 2848 г/т. В остальных пачках пласта средние содержания в 1,5-2 раза ниже кларковых.

Гафний. Повышенные содержания гафния отмечаются в пачке Нижняя-1 (в среднем 53 г/т в золе, что в 6 раз выше кларка). Среднее во всех остальных пачках пласта находится на околокларковом уровне и не превышает 13 г/т.

Скандий. Повышенные содержания скандия приурочены к пачкам Нижняя-1 и Нижняя-2 и составляют от 46 до 53 г/т в золе, что примерно в 2 раза превышает кларк. В верхних пачках содержания скандия ниже кларка в 2 раза.

Тантал. Наиболее высокие содержания тантала установлены в пачке Нижняя-1 - в среднем 5,4 г/т, что в 2,5 раза превышает кларк. Максимальное содержание -51 г/т.

Торий. Среднее содержание тория от 2 до 5 раз ниже, чем кларк, и составляет в среднем от 4,5 до 26 г/т в золе. Максимальное содержание элемента достигает 130 г/т и приурочено к пачке Нижняя-1.

Мышьяк, бром, барий, иезий, уран, рубидий, сурьма. Содержания данных элементов в несколько раз ниже кларковых значений и не представляют промышленного интереса.

Золото, серебро. Повышенных содержаний благородных металлов в пласте не выявлено. Концентрации составляют не более 0,05 и 0,1 г/т в угле соответственно. Отмечаются отдельные ураганные пробы серебра - до 66 г/т в золе.

Таким образом, следует обратить внимание на элементы, выделенные цветом в табл. 1, 2. На рис. 2 приведены элементы, концентрации которых в 1,5-3 раза превышают кларковые значения.

Ввиду того, что для некоторых элементов по отдельным пробам отмечаются ураганные концентрации, не учтенные при расчетах, фактические средние содержания могут оказаться даже выше, чем приведенные в таблицах, а список микроэлементов с повышенными содержаниями может расшириться [12].

\section{Минимальные промышленные}

содержания элементов-примесей

Оценка промышленных содержаний элементовпримесей в углях пласта «Одинокий» исследуемого месторождения проводилась на основе сопоставления с минимальными промышленными содержаниями $(M П C)$ этих элементов в известных типах руд по [6]. Графически результаты этой оценки приведены на рис. 3.

Таблица 1. Средние, минимальные и максимальные содержания РЗЭ в изученных углях (в пересчете на золу, г/m)

Table 1. Average, minimum and maximum contents of REE in the studied coal (in terms of the equivalent amount of coal ash, ppm)

\begin{tabular}{|c|c|c|c|}
\hline & $\begin{array}{l}\sum_{\mathrm{Nd}}(\mathrm{Sm}, \mathrm{Ce}, \\
\mathrm{Eu}, \mathrm{La})\end{array}$ & $\begin{array}{l}\sum_{\mathrm{Yb}, \mathrm{Tb}}(\mathrm{Lu}, \\
\text {, }\end{array}$ & \multirow{3}{*}{ Пачка/Ply } \\
\hline $\begin{array}{l}\text { Кларки } \\
\text { Bulk earth } \\
\text { values }\end{array}$ & 307,6 & 10,3 & \\
\hline МПC/MIC*** & \multicolumn{2}{|c|}{$\begin{array}{c}340 \\
\text { для } \sum(\mathrm{Y}+\mathrm{P} 3 Э) \\
\text { for } \sum(\mathrm{Y}+\mathrm{REE})\end{array}$} & \\
\hline Среднеe/Avg. & $476^{*}$ & $37 *$ & \multirow{3}{*}{$\begin{array}{c}\text { Нижняя-1 } \\
\text { Nizhnyaya-1 }\end{array}$} \\
\hline От/Min & 76 & 7,9 & \\
\hline До/Мах & 2848 & 105 & \\
\hline Среднеe/Avg. & 235 & 13 & \multirow{3}{*}{$\begin{array}{c}\text { Нижняя-2 } \\
\text { Nizhnyaya-2 }\end{array}$} \\
\hline Oт/Min & 111 & 7,3 & \\
\hline До/Мах & 384 & 22 & \\
\hline Среднеe/Avg. & 317 & 11 & \multirow{3}{*}{$\begin{array}{c}\text { Верхняя-1, северо- } \\
\text { восточный фланг } \\
\text { Verkhnyaya-1, } \\
\text { northeast area }\end{array}$} \\
\hline От/Min & 26 & 2,63 & \\
\hline До/Max & 3788 & 174 & \\
\hline Среднеe/Avg. & 153 & 5 & \multirow{3}{*}{$\begin{array}{c}\text { Верхняя 1, } \\
\text { западный фланг } \\
\text { Verkhnyaya-1, } \\
\text { west area }\end{array}$} \\
\hline Oт/Min & 31 & 1,5 & \\
\hline До/Мах & 399 & 21 & \\
\hline Среднее/Avg. & 212 & 17,5 & \multirow{3}{*}{$\begin{array}{c}\text { Верхняя-2 } \\
\text { Verkhnyaya-2 }\end{array}$} \\
\hline Oт/Min & 8 & 3 & \\
\hline До/Мах & 604 & 48 & \\
\hline
\end{tabular}

Пачка Верхняя-1 представлена самой большой выборкой проб и самым выдержанным по мощности и простиранию строением. Наибольший интерес с точки зрения МПС здесь могут представлять цинк $u$ стронций. Среднее содержание цинка составляет 709,5 г/т в золе северо-восточного фланга участка и 518 г/т в золе западного фланга участка при МПС, равном 500 г/т. Среднее содержание стронция от 1018 до 1118 г/т в золе при МПС 730 г/т.

Пачка Верхняя-2. С точки зрения оценки МПС пачка на данном этапе исследования не представляет интереса. Тем не менее в будущих работах, посвященных вопросу элементов-примесей в углях Алькатваамского угленосного района, следует обратить внимание на следующий ряд элементов, обладающий повышенными концентрациями: ичнк, кобальт и иттербий.

В пачке Нижняя-1 сконцентрировано наибольшее разнообразие элементов-примесей, которые могли бы 
представлять промышленный интерес. Легкие и тяжелые РЗЭ, сумма которых составляет 511 г/т в золе при МПС 340 г/т, скандий, содержания которого находятся на уровне МПС (53 г/т в золе), а также гафний со средними содержаниями 53 г/т в золе, что почти в 2 раза выше МПС (23 г/т).

Таблица 2. Средние, минимальные и максимальные содержания элементов-примесей в изученных углях (в пересчете на золу, г/m)

Table 2. Average, minimum and maximum contents of trace elements in the studied coal (in terms of the equivalent amount of coal ash, ppm)

\begin{tabular}{|c|c|c|c|c|c|c|c|c|c|c|c|c|c|c|c|}
\hline $\begin{array}{l}\text { Параметр } \\
\text { Parameter }\end{array}$ & $\mathrm{Ba}$ & $\mathrm{Sr}$ & $\mathrm{U}$ & Th & $\mathrm{Cr}$ & $\mathrm{Sc}$ & $\mathrm{Zn}$ & Co & $\mathrm{Hf}$ & $\mathrm{Ta}$ & Cs & $\mathrm{Rb}$ & $\mathrm{Sb}$ & As & $\mathrm{Br}$ \\
\hline Кларки/Clarks & 980 & 730 & 15 & 23 & 120 & 24 & 170 & 37 & 9 & 2 & 8 & 110 & 7,5 & 46 & 32 \\
\hline MПC/MIC $* * *$ & - & 675 & 100 & - & - & 50 & 500 & - & 23 & - & 25 & 71 & 30 & 2100 & - \\
\hline \multicolumn{16}{|c|}{ Пачка Нижняя-1/Ply Nizhnyaya-1 (зольность/ash 20,6 \%) } \\
\hline Среднее/Avg. & 38,5 & 4 & 8 & 26 & 126 & $53^{*}$ & $261 * *$ & 16 & $53 *$ & $5,4 * *$ & 0,2 & 2,8 & 2,5 & 3,5 & 11 \\
\hline Oт/Min & $<_{\text {II.o. } / \text { thr. }}$ & $<_{\text {П.о. } / \text { thr. }}$ & $<_{\Pi \text { I.o. } / \text { thr. }}$ & 1,2 & 25 & 1,7 & 39 & $<_{\text {I.o.thr. }}$ & 3,4 & $<_{\Pi \text { I.o./thr. }}$ & $<_{\text {пा.o./thr. }}$ & ח.о. /thr. & 0,5 & $<_{\text {II.o./thr. }}$ & 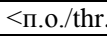 \\
\hline До/Мах & 595 & 1624 & 53 & 130 & 318 & 100 & 512 & 40 & 184,5 & 51 & 3,7 & 66 & 6,7 & 14 & 22 \\
\hline \multicolumn{16}{|c|}{ Пачка Нижняя-2/Ply Nizhnyaya-2 (зольность/ash 20,5 \%) } \\
\hline Среднее/Avg. & 69 & 58,5 & 3,4 & 11 & 125 & $46^{* * *}$ & 232 & 36 & 13 & 2,2 & 0,1 & 0,8 & 2 & 1,7 & 14 \\
\hline От/Min & <п.о./thr. & $<_{\Pi \text { п.о./thr. }}$ & $<_{\Pi \text { п.o./thr. }}$ & 1,7 & 43 & 11 & 144 & 10 & 3,9 & $<_{\text {пा.о./thr. }}$ & $<_{\text {- п.о./thr. }}$ & $<_{\text {п.о. } / \text { thr }}$ & 0,7 & < п.о./thr. & $<$ <п.о./thr \\
\hline До/Мах & 206 & 1129 & 9,5 & 27 & 258,5 & 111 & 427 & 88 & 22 & 6,2 & 7 & 37 & 4,1 & 4,1 & 43 \\
\hline \multicolumn{16}{|c|}{ Пачка Верхняя-1, северо-восточный фланг/Ply Verkhnyaya-1, northeast area (зольность/ash 6 \%) } \\
\hline Средне & 120 & $1018^{*}$ & 0,2 & 6 & 143 & 17 & $709,5 *$ & $199 * *$ & 10 & 0,6 & 0,2 & 6,5 & 5 & 2,5 & 8,3 \\
\hline Oт/Min & $<$ 无.o./thr. & $<_{\Pi \text { П.о./thr. }}$ & $<_{\Pi \text { ח.o./thr. }}$ & 1 & 51,5 & 2,6 & 269 & 5,4 & 1,1 & $<_{\Pi \text { ח.o./thr. }}$ & $<_{\text {ח..o./thr. }}$ & 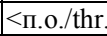 & 1,4 & $<_{\text {II.o./thr. }}$ & $<_{\text {П.о. } / \text { thr }}$ \\
\hline До/Мах & 1496 & 6155 & 24 & 49 & \begin{tabular}{|l|}
674 \\
\end{tabular} & 265 & 1517,5 & 600 & 35 & 6,8 & 28 & 226,5 & 19 & 18 & 50 \\
\hline \multicolumn{16}{|c|}{ Пачка Верхняя-1, западный фланг/Ply Verkhnyaya-1, west area (зольность/ash 8 \%) } \\
\hline Среднее/Avg. & 224 & $1118^{*}$ & 0,1 & 6,7 & 102 & 12 & $517 *$ & $159 * *$ & 7,7 & 0,8 & 0,1 & 5 & 3,3 & 6,6 & 5,5 \\
\hline От/Min & <п.о./thr. & $<_{\text {пा.о. } / \text { thr. }}$ & $<_{\text {пा.о./thr. }}$ & 0,9 & 52 & 3,1 & 139 & 40,5 & 1 & $<_{\text {п.о. } / \text { thr. }}$ & $<_{\text {—п.о./thr. }}$ & $<_{\text {п.о. } / \text { thr }}$ & 1,5 & <п.о./thr. & $<_{\text {п.о. } . / \mathrm{thr}}$ \\
\hline До/Max & 1662 & 14631 & 9,2 & 31 & \begin{tabular}{|l|}
212 \\
\end{tabular} & 27 & 13177 & 365 & 42 & 7,3 & 1,7 & 27,5 & 7,2 & 22 & 15 \\
\hline \multicolumn{16}{|c|}{ Пачка Верхняя-2/Ply Verkhnyaya-2 (зольность/ash 12,18 \%) } \\
\hline Среднее/Avg. & 175 & 424 & 2,8 & 4,5 & 80 & 13 & $311^{* *}$ & 60 *** & 4,9 & 0,5 & 0,4 & 2,7 & 2,5 & 1,1 & 6,7 \\
\hline Oт/Min & 8,8 & $<_{\Pi \text { п.о./thr. }}$ & $<_{\text {пा.o./thr. }}$ & 0,4 & 29 & 2,7 & 200 & 11 & 0,7 & $<_{\Pi \text { ח.o./thr. }}$ & $<_{\text {пा.o./thr. }}$ & 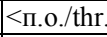 & 1,0 & $<_{\text {<ா.o./thr. }}$ & 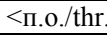 \\
\hline До/Мах & 1617 & 3053 & 24 & 79 & 245 & 118 & 3453 & 373 & 80 & 12 & 15 & 143 & 6,5 & 13 & 16 \\
\hline
\end{tabular}

Примечания к таблицам: МПС*** - минимальные промышленные содержания в известных типах руд по [6], ** повышенные содержания (в 1,5 и более раз выше кларка в золе каменных углей по [14]), * - промышленные содержания, сопоставимые с МПС в известных типах руд, п.о. - порог определения.

Notes: MIC *** - minimum industrial contents according to [6], ** - elevated level (1,5 times or more higher than bulk earth values in bituminous coal ash according [14]), * - industrial contents comparable to MIC in known ore type, thr. threshold value.

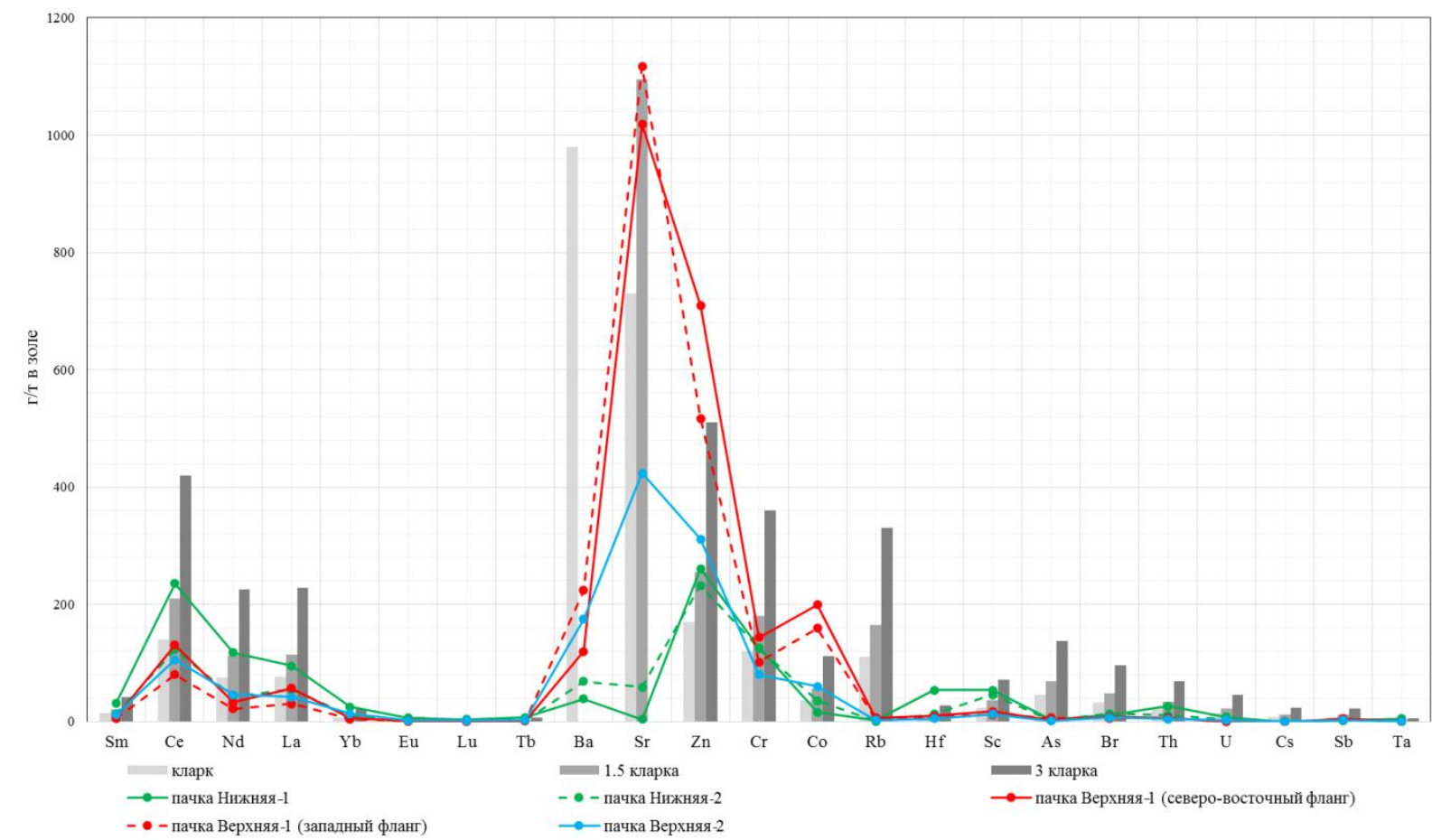

Pис. 2. Сравнение среднего содержания элементов-примесей с кларком в золе каменных углей по [14]

Fig. 2. Comparison of the average content of trace elements with bulk earth values in bituminous coal ash according to [14] 


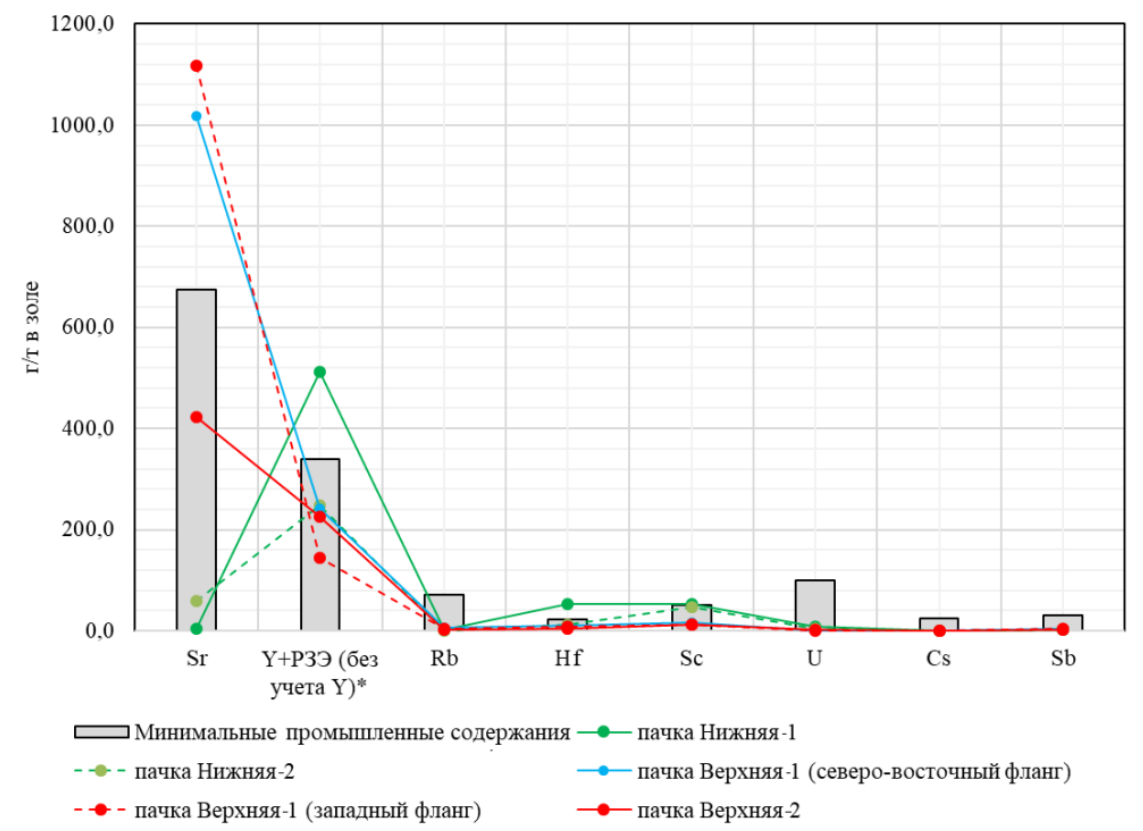

Рис. 3. Сравнительный график средних содержаний элементов-примесей и минимальных промышленных содержаний по [6]

Fig. 3. Comparative graph of the maximum and average contents of trace elements and the minimum industrial contents according to [6]

Пачка Нижняя-2. Группа нижних пачек пласта «Одинокий» имеет значительные отличия от верхних пачек по литологическому строению, по составу и содержаниям элементов-примесей. Для пачки Нижняя-2 нет достаточного количества определений (9 проб) для того, чтобы однозначно установить уровень концентрации элементов-примесей. На данном этапе исследования можно обратить внимание только на скандий, содержания которого приближаются к минимально промышленным и составляют 46 г/т при МПС 50 г/т. В целом при дальнейшем изучении данного вопроса следует учесть схожесть строения нижних пачек, которые могут оказаться аналогичными и по составу элементов-примесей.

\section{Геохимические ассоциации}

элементов-примесей в углях

На основе корреляционного анализа [11] содержаний элементов-примесей в углях месторождения «Фандюшкинское поле» выделены геохимические ассоциации. Они графически отображены на рис. 4-6, где линиями показаны значимые положительные корреляционные связи (чем толще линия, тем значительнее корреляция).

Учитывая многообразие форм нахождения элементов-примесей в углях, а также предполагая наличие нескольких источников и различных процессов, послуживших их накоплению [15-18], можно предложить изложенную ниже интерпретацию полученных данных.

В пачке Верхняя-2 надежно выделяются три геохимические ассоциации элементов (рис. 4):

1) Ассоциация типичных катионогенных литофилов $(\mathrm{Ca}, \mathrm{Rb}, \mathrm{Cs}, \mathrm{Ba})$ с группой литофилов с постоянной валентностью (Sc, тяжелых РЗЭ - Tb, Yb, Lu, и легких РЗЭ - Eu, Sm), элементов-халькофилов $(\mathrm{Fe}, \mathrm{Sb}, \mathrm{As})$ и сидерофила $\mathrm{Cr}$. Из этих элементов с зольностью значимую положительную корреляцию имеет Еu. Элементы в этой ассоциации, вероятно, находятся преимущественно в сорбционной золе [4], образованной из растворенного вещества, поступившего в торфяник извне, а также при растворении минеральных частиц терригенной (и вулканогенной) золы в торфяных водах. Для этих элементов можно предположить наличие микроминеральных форм нахождения, вероятно, связанных с ОВ углей. Также эта ассоциация отражает собственно терригенную золу, сингенетичную торфонакоплению, занесенную в торфяник из воды или воздуха. Наиболее вероятная форма нахождения элементов в терригенной золе - макроминеральная (аллотигенные глинистые минералы, карбонаты, сульфиды, оксиды, акцессорные минералы и др.). Для элементов в этой крупной ассоциации характерна криволинейная зависимость от зольности, что указывает на их нахождение в разных генетических классах золы, вероятно, существенно сорбционная золаноситель и терригенная зола-разбавитель [3].

2) Ассоциация легких Р3Э (Ce, La, Nd) и крупноионного литофила $\mathrm{Sr}$, сульфофила $\mathrm{Zn}$ и главного элемента - Na. Вероятно, источником элементов ассоциации могли послужить воды поверхностного стока, грунтовые и пластовые воды, гидротермы, питавшие древние торфяные или буроугольные залежи. Криволинейный характер зависимости от зольности предполагает присутствие этих элементов в различных генетических классах золы, при этом терригенная зола углей, вероятно, является разбавителем $[19,20]$. 


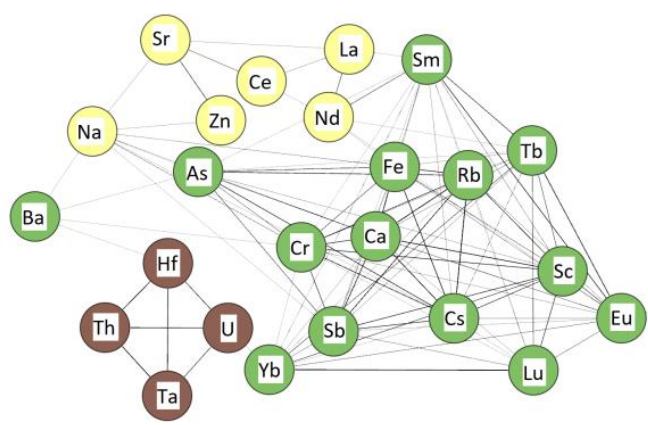

Рис. 4. Геохимические ассочиации элементов-примесей в углях пачки Верхняя-2 пласта «Одинокий». Критическое значение коэффичиента корреляиии (N=22 пробы) при уровне значимости 0,05 составляет 0,42

Fig. 4. Geochemical associations of trace elements in the Verkhnyaya-2 ply of coal seam "Odinokiy». Significant correlation coefficient is 0,42 (for $N=22$, $p=0,05$ )

3) Ассоциация высокозарядных элементов ( $\mathrm{Hf}, \mathrm{U}, \mathrm{Ta}$, $\mathrm{Th}$ ), в которой наблюдается отрицательная корреляционная связь с зольностью, существенная у урана. Скорее всего, уран находится в связи с органическим веществом углей. Вероятным источником могла быть кислая или щелочная пирокластика, массивы и дайки гранитов и гранодиоритов в обрамлении угленосного бассейна.

В пачке Верхняя-1 выделяются следующие геохимические ассоциации (рис. 5, показаны связи выше уровня коэффициента корреляции 0,3$)$ :

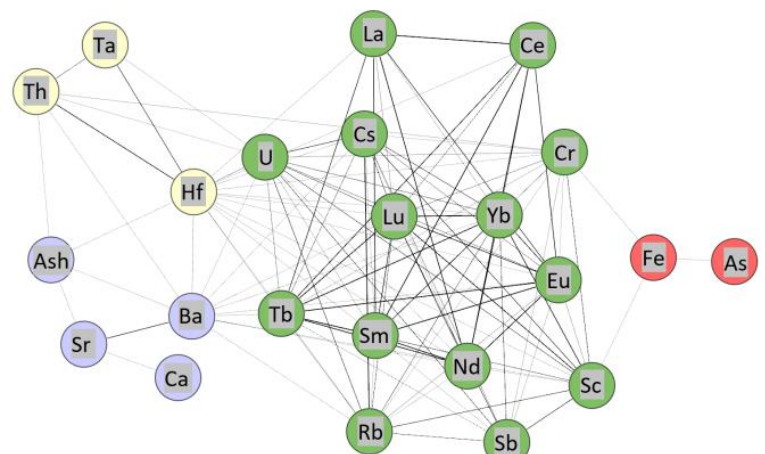

Pис. 5. Геохимические ассочиации элементов-примесей и зольности углей пачки Верхняя-1 пласта «Одинокий». Критическое значение коэффициента коррелячии (N=76 проб) при уровне значимости 0,05 составляет 0,23

Fig. 5. Geochemical associations of trace elements in the Verkhnyaya-1 ply of coal seam "Odinokiy». Significant correlation coefficient is 0,23 (for $N=76$, $p=0,05$ )

1) Ассоциация As, Fe, отвечающая сульфидам, при этом у железа отмечается значимая позитивная корреляция с зольностью $(0,27)$.

2) Группа высокозарядных элементов (Тa, Th, Hf), где $\mathrm{Hf}$ и Th коррелируют с зольностью $(0,32)$, вероятно, указывает на тот же источник этих элементов, что и в пачке Верхняя-2.
3) Ассоциация крупноионных литофилов (Ba, $\mathrm{Sr})$ с золой (Ash) и Са интерпретируется как баритовая и карбонатная минерализация, природа которой может быть как сингенетичной угленакоплению, так и эпигенетической [19].

4) Группа элементов литофилов Sc, U, тяжелых Р3Э $(\mathrm{Lu}, \mathrm{Tb}, \mathrm{Yb})$, легких Р3Э (Nd, Sm, Ce, Eu, La), крупноионных литофилов (Cs, $\mathrm{Rb})$ халькофила $\mathrm{Sb}$ при их практически отсутствующей корреляции с зольностью, интерпретируется как группа элементов, присутствующая в сорбционной и терригенной золе, и, вероятно, связанная с одним источником в области сноса, в результате гипергенного разрушения которого в различных формах произошла мобилизация этих элементов.

В нижних пачках (Нижняя-1+Нижняя-2) выделяются следующие геохимические ассоциации (рис. 6, показаны связи выше уровня коэффициента корреляции 0,4$)$ :

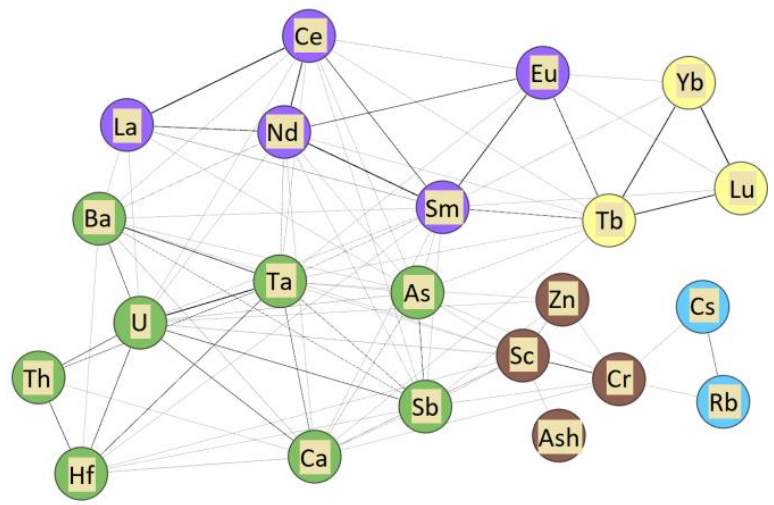

Рис. 6. Геохимические ассоциации элементов-примесей углей пачек Нижняя-1 и Нижняя-2 пласта «Одинокий». Критическое значение коэффициента корреляции ( $N=40$ проб) при уровне значимости 0,05 составляет 0,31

Fig. 6. Geochemical associations of trace elements in the Nizhnyaya-1 and Nizhnyaya-2 plies of coal seam "Odinokiy». Significant correlation coefficient is 0,31 (for $N=40, p=0,05$ )

1) Ассоциация тяжелых $\mathrm{P} 3 Э(\mathrm{Yb}, \mathrm{Tb}, \mathrm{Lu})$, имеющих очень сильную корреляцию между собой, по всей видимости, отвечает одному источнику этих элементов и одному механизму накопления в углях. Содержание этих тяжелых РЗЭ в золе углей убывает с увеличением зольности углей, что может отражать их преимущественное нахождение в сорбционной золе. При этом терригенная зола, вероятно, является разбавителем, то есть уменьшает валовое содержание этих элементов в общей золе угля [3].

2) Элементы группы $\mathrm{Sc}, \mathrm{Zn}, \mathrm{Cr}$, учитывая их значимую корреляцию с зольностью $(0,38-0,48)$, предположительно, содержатся в терригенной золе, но также могут быть сорбированы и находиться в комплексах с ОВ.

3) Отдельная ассоциация крупноионных литофилов $(\mathrm{Rb}, \mathrm{Cs})$, вероятно, отвечает гидрослюдам. 


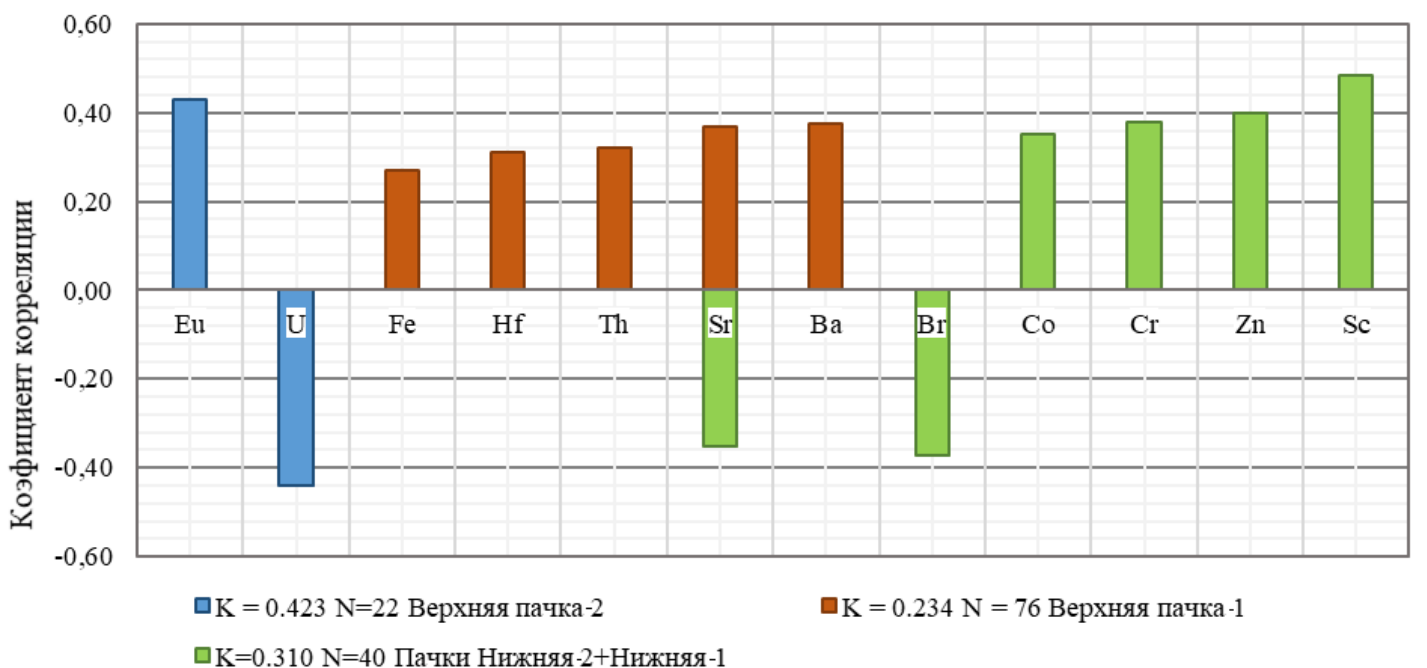

Рис. 7. Корреляиия элементов-примесей и зольности для разных пачек пласта «Одинокий»

Fig. 7. Correlation between trace elements and ash content in different plies of the seam «Odinokiy»

Учитывая полученные данные, можно сделать предположения об источнике основных элементовпримесей, которые могут представлять промышленный интерес (цинк, стронций, гафний, скандий и РЗЭ)

Цинк не коррелирует с зольностью в верхних пачках (рис. 7), но достаточно хорошо коррелирует в нижних пачках. Вероятно, цинк может содержаться не только во внешней золе, но и в значительной мере во внутренней. Также это может объясняться сменой фациальных особенностей углеобразования. В верхней пачке цинк идет в связке со стронцием, а в нижней - самостоятельно, в группе транзитных элементов. Условием фиксации цинка в обстановке торфяных болот является подщелачивание среды, а его связь со стронцием может указывать на влияние морских вод на обстановку угленакопления. Накопление в углях $\mathrm{Zn}$ могло быть результатом эпигенетических процессов, для которых характерен литологический контроль минерализации.

Стронщий имеет корреляцию с зольностью в верхней пачке. В изверженных породах - возможных источниках терригенного стронция, он в основном встречается в плагиоклазах и калиевом полевом шпате [16]. На рассматриваемой территории это могли быть породы позднемеловой и палеогеновой гранитгранодиоритовых формаций, расположенные в северо-западном обрамлении Беринговского каменноугольного бассейна (рис. 8). Накопление стронция также могло происходить при трансгрессии моря на прибрежные торфяники [4]. Формирование МПС стронция в углях могло также носить эпигенетическим характер.

Скандий. По данным [4] отмечается присутствие скандия в сидеритах, кальцитах и глинистом веществе из углей. В нижних пачках пласта наблюдается множество сидеритовых конкреций, предположительно, с ними могут быть связаны повышенные содержания скандия. Скандий имеет значительную положительную корреляцию с зольностью.

Гафний. Так как этот элемент в нижних пачках не коррелирует с зольностью, то, возможно, он содер- жится преимущественно в форме $\mathrm{Hf}_{\text {орг }}$. Обогащение большинства углей гафнием сингенетическое и контролируется составом терригенного петрофонда и примесями кислой пирокластики [3]. Гафний в нижних пачках идет в связке с ураном, торием, что может указывать на единый источник поступления элементов.

Редкоземельные элементы, повышенные концентрации которых отмечаются в нижних пачках пласта, не коррелируют с зольностью. Предположительно они могут находиться в углях в органической форме.

Источники элементов-примесей.

Минерагеническая специализация территории

Беринговского каменноугольного бассейна

Территория Беринговского каменноугольного бассейна относится к двум минерагеническим провинциям - Беринговоморской и Беринговоморско-Чукотской. В минерагеническом отношении ведущая роль принадлежит позднемеловому и кайнозойскому магматизму, связанному с раздвиговыми процессами Беринговоморского вулканоплутонического пояса [10].

Непосредственно изучаемый район расположен на территории Алькатваам-Варапелинской минерагенической зоны, в ее Алькатваамской части. В целом для нее характерны выходы позднемеловых-палеогеновых угленосных отложений и незначительные проявления рудных полезных ископаемых: позднемеловая золотоносная медно-порфировая формация, палеогеновые оловорудные зоны дробления, мел-кайнозойское ртутно-сурьмяное и вольфрам-ртутное оруденение.

Алькатваам-Варапелинская зона расположена в обрамлении Майницко-Эконайской рудной зоны, богатой на проявления ртути, вольфрама, золота, платины, хрома, меди, сурьмы, мышьяка. Можно выделить несколько этапов минерализации. Первый связан с породами позднеюрского-раннемелового офиолитового комплекса (хромитовые платино- и золотоносные руды, собственно золоторудные формации, никелевое оруденение, жильные проявления барита, асбест, поделочные камни). 


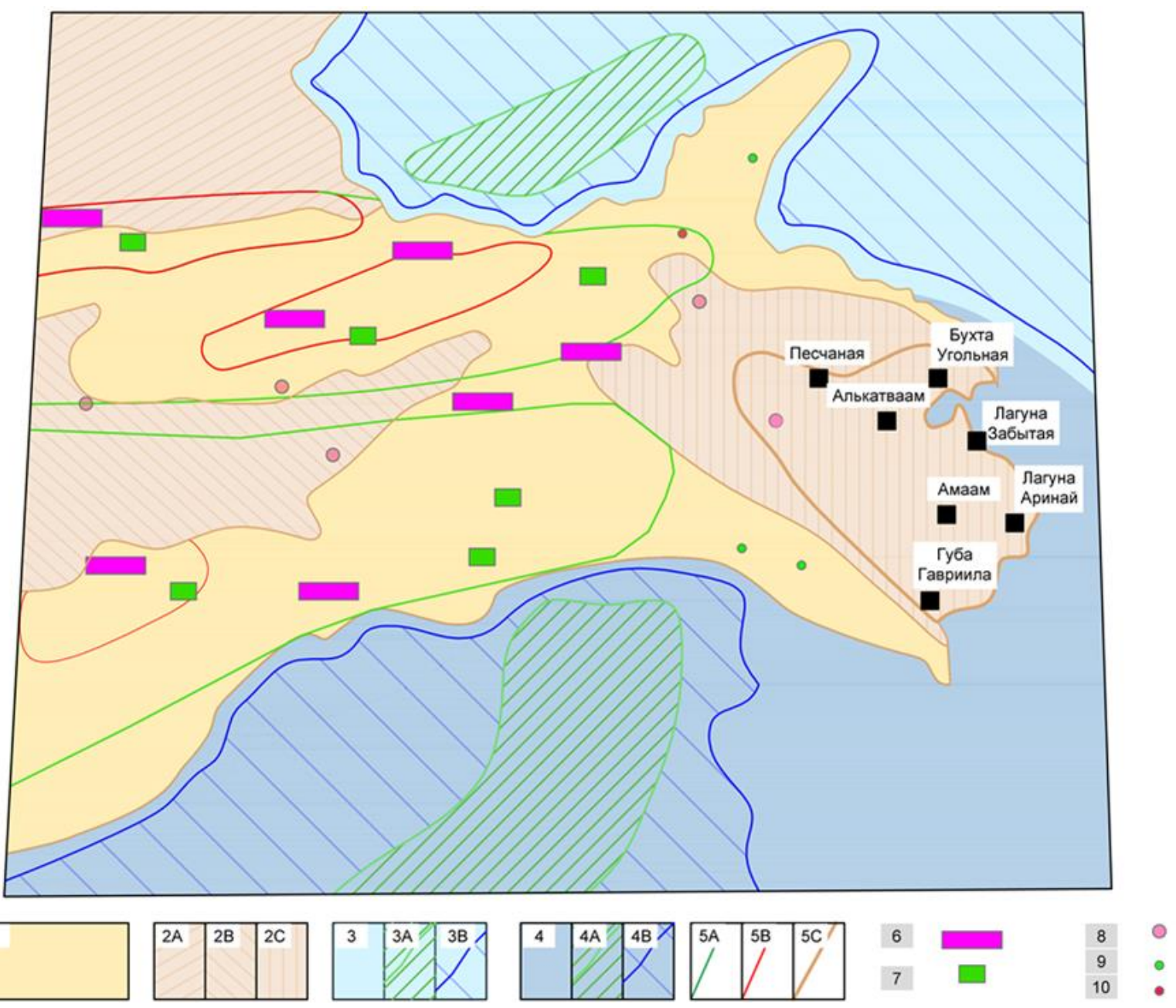

Рис. 8. Обзорная схема минерагенического районирования юго-восточной Чукотки*. Условные обозначения: 1 Майницко-Эконайская минерагеническая зона ( $\mathrm{Hg}, \mathrm{W}, \mathrm{Au}, \mathrm{Pt}, \mathrm{Cr}, \mathrm{Cu}(\mathrm{Sb}, \mathrm{As}) ; 2$ - Алькатваам-Варапелинская минерагеническая зона (Аи, уголь каменный, $\mathrm{Cu}, \mathrm{Sn},(\mathrm{Hg}, \mathrm{Sb})$, фрагменты: $2 A$ - Алгано-Великореченский, $2 B-$ Варапелинский, 2C-Алькатваамский; 3 - Анадырская минерагеническая зона (газ, нефть, (уголь бурый, Аи?): $3 A$ - Поворотно-Телекайская нефтегазоносная зона, 3B - Анадырский нефтегазоносный бассейн; 4 - Хатырская минерагеническая зона (нефть, газ (битум, воды минеральные): 4А-Угловая нефтегазоносная зона, $4 B$ - Хатырский нефтегазоносный бассейн; $5 A$-металлогенические зоны с золотым и медным оруденением преимущественно золото-квариевой и медноколчеданной формачий; $5 B$ - металлогенические зоны с оруденением металлов платиновой группы в хромитовых гипербазитах (предполагаемые); 5С - Беринговский каменноугольный бассейн; Островодужные формачии: 6 - Позднеюрская-раннемеловая дунит перидотитовая формация (Cr, Au, Hg, (Pt, Ni, асбест, камни поделочные); 7 - Позднеюрская-раннемеловая габбровая, раннемеловая плагиогранитовая и габбровая формации (Cu, $\mathrm{Zn}, \mathrm{Pb},(\mathrm{Au}, \mathrm{Mo})$; Формации Беринговоморского вулканоплутонического пояса невадийского типа: 8 - Позднемеловая гранодиорит-гранитовая формация (Сu, $(\mathrm{Au}, \mathrm{Ag}, \mathrm{Mo}) ; 9$ - Палеогеновая габбродиорит-габбровая и базальтовая формации (Au); 10 - Палеогеновая гранит-гранодиоритовая формачия (Sn). *Примечание: Схема составлена на основе данных [10] с использованием электронных информачионных ресурсов ВСЕГЕИ им. Карпинского

Fig. 8. Overview scheme of mineragenic zoning of southeastern Chukotka [10]*. Legend: 1 - Mainitsko-Ekonaysky mineragenic zone ( $\mathrm{Hg}, \mathrm{W}, \mathrm{Au}, \mathrm{Pt}, \mathrm{Cr}, \mathrm{Cu}(\mathrm{Sb}, \mathrm{As}) ; 2$ - Alkatvaam-Varapelinsky mineragenic zone ( $\mathrm{Au}$, coal, $\mathrm{Cu}, \mathrm{Sn}$, $(\mathrm{Hg}, \mathrm{Sb})$, fragments: 2A - Algano-Velikorechensky, 2B - Varapelinsky, 2C - Alkatvaamsky 3; Anadyr mineragenic zone (gas, oil, (brown coal, Au?): 3A - Povorotno-Telekai petroleum zone, 3B - Anadyr petroleum basin; 4 - Khatyr mineragenic zone (oil, gas (bitumen, water mineral): $4 A$ - Uglovaya petroleum zone, $4 B$ - Khatyr petroleum basin; $5 A$ - metallogenic zones with gold and copper mineralization, predominantly gold-quartz and copper-sulphide formations; $5 B$ - metallogenic zones with mineralization of platinum group metals in chromite ultrabasite rocks (supposititious); 5C - Bering coal basin; Arc formations: 6 - Late Jurassic-Early Cretaceous dunite peridotite formation (Cr, Au, $\mathrm{Hg}$, (Pt, Ni, asbestos, ornamental stones); 7 - Late Jurassic-Early Cretaceous gabbro, Eearly Cretaceous plagiogranite and gabbro formations $(\mathrm{Cu}, \mathrm{Zn}, \mathrm{Pb},(\mathrm{Au}, \mathrm{Mo})$; Formations of the Bering Sea volcanoplutonic belt of the Nevada type: 8 - Late Cretaceous granodiorite-granite formation (Cu, (Au, Ag, Mo); 9 Paleogene gabbrodiorite-gabbro and basaltic formations (Au); 10 - Paleogene granite-granodiorite formation (Sn). *Note: The scheme was based on the data [10] using electronic information resources of Karpinsky Russian Geological Research Institute (VSEGEI) 
Второй этап связан с позднемеловой-кайнозойской аккрецией, надвиговыми и сбросовыми процессами. Здесь выделяются ртутные, вольфрамово-ртутные оруденения лиственитового типа, сменяющиеся по латерали ртутно-мышьяковым и ртутно-сурьмяным оруденением. Оруденение золотосульфидно-кварцевой формации приурочено к жилам в палеогеновых долеритах [10]. Алькатваамская минерагеническая зона формировалась в условиях островодужной геодинамической обстановки. Она включает в себя среднепалеозойские карбонатно-кремнисто-вулканогенные, триасовые и позднеюрские - раннемеловые вулканогенно-терригенные формации (золото, медь, цинк, свинец - минерагеническая специализация). Данные формации, подстилающие угленосные отложения, могут быть источниками цинка и стронция в углях. Также в зону входят отложения более поздних обстановок Беринговоморского вулканоплутонического пояса, внутриконтинентальных межгорных впадин, коньяк-палеоценовая молассоидная терригенная угленосная формация. Южная граница Алькатввамской-Варапелинской зоны, по разломам, характеризуется проявлениями ртути. Северо-западная граница проявлениями золота, никеля и ртути, также по разломам. В северо-западном обрамлении угленосного бассейна выделяется позднемеловая гранодиоритгранитовая формация со специализацией $\mathrm{Cu}(\mathrm{Au}, \mathrm{Ag}$, Мо). Не исключено, что данная формация могла послужить источником гафния и РЗЭ в углях. С позднеюрско-раннемеловой дунит-перидотитовой формацией, выделяемой в западном обрамлении бассейна, связаны проявления ртути, золота, никеля и, вероятно, повышенные содержания скандия в исследуемых углях. Широко распространенные гидротермальнометасоматические изменения пород, установленные в районе исследования, среди которых преобладает

\section{СПИСОК ЛИТЕРАТУРЫ}

1. Юдович Я.Э., Кетрис М.П. Неорганическое вещество углей. Екатеринбург: УрО РАН, 2002. - 422 с

2. Юдович Я.Э., Кетрис М.П. Ценные элементы-примеси в углях. - Екатеринбург: УрО РАН, 2006. - 538 с.

3. Шишов Е.П., Богомолов А.Х. Многоэлементная металлоносность Корфского и Эчваямского буроугольных месторождений (Камчатка) // Вестн. Моск. Ун-та. Сер. 4. Геология. 2014. - № 6. - C. 70-75.

4. Вялов В.И., Наставкин А.В. Уровни содержания промышленно ценных микроэлементов в углях // Химия твердого топлива. - 2019. - № 5. - С. 63-67.

5. Ценные металлы в углях Арктической зоны России / В.И. Вялов, А.Х. Богомолов, А.В. Наставкин, Е.В. Кузеванова, Е.П. Шишов, А.А. Чернышев // Георесурсы. - 2019. - № 21 (2). C. 53-62.

6. Угольные месторождения Дальнего Востока России и ресурсный потенциал содержащихся в них ценных металлов / В.И. Вялов, А.Х. Богомолов, Е.П. Шишов, А.А. Чернышев // Георесурсы. - 2017. - Спецвыпуск. - Ч. 2. - С. 256-262.

7. Фандюшкин Г.А., Иванов Н.И., Ломидзе В.С. Геологический отчет с подсчетом запасов и оценкой прогнозных ресурсов угля по результатам оценочных работ на участке Западный Амаамского каменноугольного месторождения Беринговского бассейна. - Владивосток: Трест Дальвостуглеразведка, 2011. $267 \mathrm{c}$.

8. Фандюшкин Г.А. Поисковые работы на участке «Левобережный» Верхне-Алькатваамского месторождения Беринговского карбонатизация, реже сульфидизация и окварцевание, могли значительно повлиять на процессы мобилизации и накопления элементов-примесей в углях месторождения «Фандюшкинское поле» Беринговского каменноугольного бассейна [10]

\section{Заключение}

Промышленное значение элементы-примеси могут получить лишь в случае, если их концентрации в продуктах обогащения и переработки угля, а также технология последующего извлечения обеспечивают целесообразность добычи этих компонентов по технико-экономическим показателям [6].

Обобщая вышеизложенную информацию, можно сделать вывод, что четыре отдельные пачки пласта «Одинокий» месторождения «Фандюшкинское поле» достаточно отличаются друг от друга по составу и содержаниям элементов-примесей.

Наличие повышенных концентраций, сравнимых с МПС, предполагается для следующих элементов: в пачке Нижняя-1 - гафний, скандий, сумма редкоземельных элементов (иттербий, тербий, лютеций, самарий, церий, неодим, европий, лантан). В пачке Верхняя-1 - цинк и стронций. Пачка Верхняя-2 отличается повышенными содержаниями цинка, кобальта и иттербия только относительно кларка. Пачка Нижняя-2 - повышенными содержаниями скандия относительно кларка. Таким образом, особое внимание при дальнейших исследованиях следует обратить на угольные пачки Верхняя-1 и Нижняя-1.

Исследование выполнено за счет гранта Российского научного фонда (проект № 18-17-00004).

Авторы благодарят Арбузова Сергея Ивановича и Вялова Владимира Ильича за иенные консультачии и помощь 8 проведении исследования.

каменноугольного бассейна. Геологический отчет с подсчетом запасов и оценкой прогнозных ресурсов угля на участке «Фандюшкинское поле». - М.: ООО «Берингпромуголь», 2013. -455 c

9. Коксующиеся угли Арктической зоны России / В.И. Вялов, А.Б. Гуревич, Г.М. Волкова, Д.А. Скиба, Е.П. Шишов, А.А. Чернышев // Георесурсы. - 2019. - № 21 (3). - С. 111-129.

10. Государственная геологическая карта Российской Федерации. Масштаб 1:000000 (новая серия). Лист Р-60 - мыс Наварин. Объяснительная записка. - СПб.: Изд-во СПб картфабрики ВСЕГЕИ, 2001. - 162 с

11. Девис Дж.С. Статистический анализ данных в геологии. В 2 кн./ пер. с англ. В.А. Голубевой, под ред. Д.А. Родионова. - М.: Недра, 1990. - Кн. 1. -319 c.

12. Чини Р.Ф. Статистические методы в геологии / Пер. с англ. М.: Мир, 1986. - 189 с.

13. Conover W.J. Practical nonparametric statistics. 3rd ed. Australia: John Wiley \& Sons, 1999. - 584 p.

14. Ketris M.P., Yudovich Y.E. Estimations of clarkes for carbonaceous biolithes: world averages for trace element contents in black shales and coal // International Journal of Coal Geology. 2009. - V. 78. - P. 135-148.

15. Wagner N.J., Matiane A. Rare earth elements in select Main Karoo Basin (South Africa) coal and coal ash samples // International Journal of Coal Geology. - 2018. - V. 196. - P. 82-92.

16. Мейсон Б. Основы геохимии / Пер. с англ. - М.: Недра, 1971. $-312 \mathrm{c}$.

17. Henderson P. Rare earth element geochemistry. - Amsterdam: Elsevier Science, 1983. $-510 \mathrm{p}$ 
18. Killops S.D., Killops V.J. Introduction to organic geochemistry. 2nd ed. - New York: Wiley-Blackwel, 2013. - 408 p.

19. Handbook of geochemistry. Elements $\mathrm{Kr}(36)$ to $\mathrm{Ba}(56)$. - Berlin; Heidelberg: Springer-Verlag, 1974. - V. 2. - P. 4. - 950 p.
20. Handbook of geochemistry. Elements $\mathrm{Cr}(24)$ to $\mathrm{Br}(35)$. - Berlin; Heidelberg: Springer-Verlag, 1972. - V. 2. - P. 3. - 897 p.

Поступила 25.11.2020 2.

\section{Информация об авторах}

Скиба Д.А., аспирант отдела геологии горючих полезных ископаемых, Всероссийский научноисследовательский геологический институт им. А.П. Карпинского.

Kузеванова E.B., кандидат геолого-минералогических наук, младший научный сотрудник, Московский государственный университет им. М.В. Ломоносова, геологический факультет, кафедра геологии и геохимии горючих ископаемых.

Шишов Е.П., старший научный сотрудник отдела геологии горючих полезных ископаемых, Всероссийский научно-исследовательский геологический институт им. А.П. Карпинского. 
UDC 553.94:550.4

\title{
TRACE ELEMENTS IN THE FANDYUSHKINSKOE POLE COAL DEPOSIT (BERING COAL BASIN, CHUKOTKA)
}

\author{
Daria A. Skiba ${ }^{1}$ \\ dariaskib@bk.ru
}

\section{Evgenia V. Kuzevanova², e.kuzevanova@oilmsu.ru}

\author{
Evgeniy P. Shishov ${ }^{1}$, \\ e-shishov@mail.ru
${ }^{1}$ A.P. Karpinsky Russian Geological Research Institute, 74, Sredny prospect, St. Petersburg, 199106, Russia.
2 Lomonosov Moscow State University, GSP-1, 1, Leninskie Gory, Moscow, 119991, Russia.

\begin{abstract}
Relevance. The study of possibility of complex processing of coals of Bering coal basin for extracting rare metals and various trace elements is caused by the necessity of economic development and improvement of security of the Chukotka Autonomous Region. This is especially important in the context of its geographical location in the Far North and its poor accessibility. Nowadays, due to their relatively high cost of production and increased ash-content (up to $30 \%$ ), the coals of the lower members of the Fandyushkinskoe Pole coal deposit are in low demand in the market, although they make up a significant part of the reserves. The potential opportunity to evaluate these coals also for presence of useful additional elements could increase the value of the extracted raw materials.

The aim of the research is to determine the prospects of the territory from the point of view of increased content of trace elements and to identify the areas for the further research.

Objects: the Bering coal basin, Late Cretaceous coal deposits of the Alkatvaam coal-bearing region, the Fandyushkinskoe Pole coal deposit and its flanks.

Methods: samples collection, construction of lithological columns and sections, instrumental neutron activation analysis.

Results. The authors have given the geochemical characteristics of the coals of the Fandyushkinskoe Pole coal deposit (the Alkatvaam coal-bearing region, the Chukotka Autonomous Region) based on the data obtained by instrumental neutron activation analysis. It was discovered that in the coals of the Fandyushkinskoe Pole field deposit of the Bering coal basin and its flanks, concentrations of zinc, strontium, hafnium, scandium and rare earth elements can be at the level of minimum industrial grade in identified types of ores. The data on content of some trace elements in coals of the studied deposit are published for the first time.
\end{abstract}

\section{Key words:}

Coals, trace elements in coal, rare metal, rare-earth elements, instrumental neutron activation analysis, Chukotka.

The research was carried out on account of the grant of the Russian Science Foundation (project no. 18-17-00004).

The authors appreciate S.I. Arbuzov and V.I. Vyalov for valuable advice and assistance in conducting the study.

\section{REFERENCES}

1. Yudovich Ya.E., Ketris M.P. Neorganicheskoe veshchestvo ugley [Inorganic substance of coals]. Yekaterinburg, Ural department of RAS Publ., 2002. 422 p.

2. Yudovich Ya.E., Ketris M.P. Tsennye elementy-primesi v uglyakh [Valuable trace elements in coals]. Yekaterinburg, Ural department of RAS Publ., 2006. 538 p.

3. Shishov E.P., Bogomolov A.Kh. Multielement metalliferousness of the Korfsky and the Echvayamsky brown coal deposits (Kamchatka)]. Journal of Moscow University, ser. 4. Geology, 2014, no. 6, pp. 70-75. In Rus.

4. Vyalov V.I., Nastavkin A.V. Concentration levels of industrially valuable trace elements in coals. Solid fuel chemistry, 2019, no. 5, pp. 63-67. In Rus.

5. Vyalov V.I., Bogomolov A.Kh., Nastavkin A.V., Kuzevanova E.V., Shishov E.P., Chernyshev A.A. Valuable metals in coals of the Russian Arctic Zone. Georesurces, 2019, vol. 21, no. 2, pp. 53-62. In Rus.

6. Vyalov V.I., Bogomolov A.Kh., Shishov E.P., Chernyshev A.A Coal deposits of the Far East Russia and resource potential of precious metals contained in them. Georesources, 2017, Special issue, P. 2, pp. 256-262. In Rus.

7. Fandyushkin G.A., Ivanov N.I., Lomidze V.S. Geologicheskiy otchet s podschetom zapasov i otsenkoy prognoznykh resursov uglya po rezultatam otsenochnykh rabot na uchastke Zapadny Amaamskogo kamennougolnogo mestorozhdeniya Beringovskogo basseyna [Geological report with reserves estimation and assessment of forecasted coal resources based on the results of evaluations at the Western Amaamsky coal deposit of the Bering basin]. Vladivostok, Trest Dalvostuglerazvedka Publ., 2011. 267 p.

8. Fandyushkin G.A. Poiskovye raboty na uchastke "Levoberezhny» Verkhne-Alkatvaamskogo mestorozhdeniya Beringovskogo kamennougolnogo basseyna. Geologicheskiy otchet s podschetom zapasov $i$ otsenkoj prognoznykh resursov uglya na uchastke «Fandyushkinskoe pole» [Exploration works at the Levoberezhniy site of the Verkhne-Alkatvaamskoe field of the Bering coal basin. Geological report with reserves estimation and estimation of forecasted coal resources at the Fandyushkinskoe Pole field site]. Moscow, OOO «Beringpromugol» Publ., 2013. 455 p.

9. Vyalov V.I., Gurevich A.B., Volkova G.M., Skiba D.A. Shishov E.P., Chernyshev A.A. Coking coals of the Arctic zone of Russia. Georesources, 2019, no. 21 (3), pp. 107-124. In Rus.

10. Gosudarstvennaya geologicheskaya karta Rossiyskoy Federatsii. Masshtab 1:000000 (novaya seriya). List R-60 - mys Navarin. Obyasnitelnaya zapiska [State geological map of the Russian Federation. Scale 1:000000 (new series). Sheet P-60 - Cape Navarin. Explanatory letter]. St. Petersburg, St. Petersburg Mapfactory of VSEGEI Publ. house, 2001. $162 \mathrm{p}$. 
11. Davis J.C. Statistics and data analysis in geology. $2^{\text {nd }}$ ed. New York, John Wiley and Sons Publ., 1986. 656 p.

12. Cheeney R.F. Statistical methods in geology for field and lab decisions. London, Allen and Unwin Publ., 1983. 169 p.

13. Conover W.J. Practical nonparametric statistics. $3^{\text {rd }}$ ed. Australia, John Wiley \& Sons Publ., 1999. $584 \mathrm{p}$.

14. Ketris M.P., Yudovich Ya.E. Estimations of clarkes for carbonaceous biolithes: world averages for trace element contents in black shales and coal. International Journal of Coal Geology, 2009, no. 78, pp. 135-148.

15. Wagner N.J,. Matiane A. Rare earth elements in select Main Karoo Basin (South Africa) coal and coal ash samples. International Journal of Coal Geology, 2018, no. 196, pp. 82-92.
16. Mason B. Principles of geochemistry. $3^{\text {rd }}$ ed. New York, John Wiley and Sons Publ., 1966. 329 p.

17. Henderson P. Rare earth element geochemistry. Amsterdam, Elsevier Science Publ., 1983. 510 p.

18. Killops S.D., Killops V.J. Introduction to organic geochemistry. $2^{\text {nd }}$ ed. New York, Wiley-Blackwel Publ., 2013. 408 p.

19. Handbook of geochemistry. Elements $\mathrm{Kr}$ (36) to Ba (56). Berlin, Heidelberg, Springer-Verlag Publ., 1974. Vol. 2, P. 4, 950 p.

20. Handbook of geochemistry. Elements $\mathrm{Cr}$ (24) to Br (35). Berlin, Heidelberg, Springer-Verlag Publ., 1972. Vol. 2, P. 3, 897 p.

Received: 25 November 2020.

\section{Information about the authors}

Daria A. Skiba, graduate student, A.P. Karpinsky Russian Geological Research Institute.

Evgenia V. Kuzevanova, Cand. Sc., researcher, Lomonosov Moscow State University.

Evgeniy P. Shishov, senior researcher, A.P. Karpinsky Russian Geological Research Institute. 